\title{
Effect of seed priming on growth parameters of Okra (Abelmoschus esculentus L.)
}

Inayat-ur-Rahman ${ }^{*}$, Shamsher ali², Inayat-ur-Rahman ${ }^{3}$, Muhammad Adnan $^{1}$, Muhammad Ibrahim ${ }^{1}$, Nauman Saleem ${ }^{4}$ and Irshad Ali Khan ${ }^{1}$

1. Dept. of Agriculture (Horticulture), University of Swabi, Swabi, Pakistan

2. Department of Soil and Environmental Sciences Agricultural University Peshawar Amir Muhammad khan Hoti Campus Mardan, Pakistan

3. Pakistan Council of Scientific and Industrial Research (PCSIR), Pakistan

4. University of Swabi, Swabi, Pakistan

*Corresponding author's email: atabcs@yahoo.com

Citation

Inayat-ur-Rahman, Shamsher ali, Inayat-ur-Rahman, Muhammad Adnan, Muhammad Ibrahim, Nauman Saleem and Irshad Ali Khan. Effect of seed priming on growth parameters of Okra (Abelmoschus esculentus L.) Pure and Applied Biology. Vol. 5, Issue 1, 2016, pp165-171. http://dx.doi.org/10.19045/bspab.2016.50021

\begin{tabular}{llll}
\hline \hline Received: 31/10/2015 & Revised: 08/12/2015 & Accepted: 20/12/2015 & Online First: 01/02/2016 \\
\hline \hline
\end{tabular}

\section{Abstract}

To study the effect of seed priming on growth parameters of okra, a field experiment was conducted in 2013. For this experiment, seeds were primed in PEG-8000 (polyethylene glycol) and Mannitol solutions having 0, -0.4, -0.8, -1.2, -1.6, -2 and -2.4 Mpa osmotic potential while dry seeds were used as control. Randomized complete block design (RCBD) with two factors and sixteen treatments replicated three times was used for this experiment. Field experiment results showed that days to flowering, days to edible maturity, plant height, absolute growth rate and relative growth rate were unaffected by priming agents but significantly affected by osmotic potential, reduction indays to flowering and days to edible maturity occurred as osmotic potential increased from -2.4 to $0 \mathrm{Mpa}$. Maximum absolute growth rate was recorded at $-1.2 \mathrm{Mpa}$ osmotic potential. Significantly lowest plant height was recorded for plants raised from unprimed seeds followed by plants raised from seeds primed at lowest osmotic potential i.e at -2.4 and $-2 \mathrm{Mpa}$ osmotic potential respectively while highest plant height was recorded for $-1.2 \mathrm{Mpa}$ and above this osmotic potential. Highest relative growth rate was recorded for plants grown from unprimed seeds and seeds primed at lower osmotic potential while lowest relative growth rate was observed for plants raised from seeds which were primed at higher osmotic potential.

Keywords: Okra; Polyethylene glycol 8000; Mannitol; Osmotic potential; Seed priming

\section{Introduction}

Seed priming is a pre-sowing seed treatment in which seed is allowed to imbibe enough water to start pregerminative metabolic processes but insufficient for radicle protrusion because with radicle protrusion seed loses its desiccation tolerance [1]. After hydration, treated seeds are dried back to their initial moisture content. This drying back process is called hydration dehydration and is practiced to minimize deterioration in seed during storage. Priming improves seed germination performance by starting early processes of germination but not cell 
division [2]. Metabolism that occurs during priming is not enough to cause radicle emergence.

In the two types of seed priming, in one type water penetrate freely into seed which is called hydropriming while in other type seed hydration is controlled. If controlled hydration is achieved through the addition of solute to water then it is called osmopriming or if a solid matrix is used to provide controlled seed hydration then it is called solid matrix priming [3].

Seed priming improves germination performance of seed [3, 4]. Osmopriming strengthens the antioxidant system and increase seed germination potential, resulting in an increased stress tolerance in germinating seeds [5]. Response of seed to priming is affected by priming duration [5], osmotic potential of priming solution [6], priming agent [7] and oxygen supply to seed [8]. Priming also cause early flowering [9, 10], enhances growth rate [11-13] and increase plant height $[12,14]$.

Okra seeds contain proteins, unsaturated fattyacids, vitamin B6, folic acid, fibre and relatively low amount of copper, iron, manganese and zinc [15]. According to USDA Nutrient database, per $100 \mathrm{gm}$ of okra contain $7.03 \mathrm{~g}$ carbohydrates, $1.20 \mathrm{~g}$ sugars, $3.2 \mathrm{~g}$ dietary fiber, $0.10 \mathrm{~g}$ fat, $2 \mathrm{~g}$ protein, $90.17 \mathrm{~g}$ water and $129 \mathrm{KJ}$ energy.

Main problem in okra is slow growth and unsynchronized flowering and maturity. So the main goal of this research work was to overcome this problem through seed priming and to optimize osmotic potential and priming agent for okra seed priming.

\section{Materials and methods}

This experiment was conducted during 2013 at Agricultural Research Farm of Khyber Pukhtunkhwa Agricultural University, Peshawar (Pakistan). The experimental site was located at $34^{\circ} \mathrm{N}, 71.3^{\circ} \mathrm{E}$ and an altitude of $317 \mathrm{~m}$ above sea level. Soil of the experimental field was silty clay loam, low in nitrogen $(0.03-0.04 \%)$, low in organic matter $(0.7-0.9 \%)$ and alkaline in reaction ( $\mathrm{pH}$ 7.3-7.5). Seeds were primed in PEG 8000 and Mannitol solutions having osmotic potential $0,-0.4,-0.8,-1.2,-1.6,-1.2$ and $2.4 \mathrm{Mpa}$ while dry seeds were used as control. After priming, the seeds were rinsed with water and then dried to initial moisture content at room temperature. After drying, 100 seeds of each treatment were sown on $20^{\text {th }}$ April, 2013 in well prepared plots of $6.75 \mathrm{~m}^{2}$ with seed to seed distance of $15 \mathrm{~cm}$ and row to row distance of $45 \mathrm{~cm}$. Weeding was done twice and the field was irrigated four times. Osmotic potentials of priming solutions were determined according to [15]. Aquarium pump was used for adequate supply of oxygen to the priming solution. The experiment was laid out in Randomized Complete Block Design (RCBD), with two factors for analyzing 16 treatments replicated three times (Two priming agents with seven levels of each while dry seeds were used as the eighth level).Data were recorded on the following parameters.

\section{Days to flowering}

Days to flowering were determined from date of sowing to date of flowering.

\section{Days to maturity}

Like days to flowering days to maturity were determined from date of sowing to date of maturity.

\section{Plant height in $\mathbf{c m}$}

For plant height determination four plants were randomly selected in each plot after 80 days of sowing and plant height of each plant was noted from which average plant height was calculated.

\section{Absolute growth rate (AGR)}

It was determined from the dry matter content of plant through the following formula:

$\mathrm{AGR}=\mathrm{W}_{2}-\mathrm{W}_{1} / \mathrm{T}_{2}-\mathrm{T}_{1}$

Relative growth rate (RGR)

$\mathrm{RGR}=\ln \mathrm{W}_{2}-\ln \mathrm{W}_{1} / \mathrm{T}_{2}-\mathrm{T}_{1}$

Where 
$\mathrm{W}_{1}=1^{\text {st }}$ weight

$\mathrm{W}_{2}=2^{\text {nd }}$ weight

$\ln \mathrm{W}_{1}=$ natural $\log$ of $1^{\text {st }}$ weight

$\ln \mathrm{W}_{2}=$ natural $\log$ of $2^{\text {nd }}$ weight

$\mathrm{T}_{1}$ and $\mathrm{T}_{2}$, show $1^{\text {st }}$ and $2^{\text {nd }}$ time.

Results

Seed priming effect on days to flowering

Statistical analysis of the data indicated that osmotic potential significantly $(\mathrm{P} \leq 0.05)$ affected earliness to flowering while insignificant effect was found for priming agents and their interaction with osmotic potential.

Table 1 represents data on days to flowering as a function of priming versus dry seeds. Statistically plants raised from sowing dry seeds took maximum days (36.1) to flowering. It was statistically similar to those plants raised from seeds primed at -2 and -2.4 Mpa osmotic potential. Priming with just water (0 Mpa osmotic potential) has enhanced flowering by two days as compared to dry seeds and seeds primed at lowest osmotic potential.

Table 1. Days to flowering as affected by seed priming

\begin{tabular}{|l|l|l|l|l|l|l|l|l|l|}
\hline Priming Agent & \multicolumn{10}{|c|}{ Osmotic potential } \\
& 0 & $\begin{array}{l}-0.4 \\
\text { Mpa }\end{array}$ & $\begin{array}{l}-0.8 \\
\text { Mpa }\end{array}$ & $\begin{array}{l}-1.2 \\
\text { Mpa }\end{array}$ & $\begin{array}{l}-1.6 \\
\text { Mpa }\end{array}$ & $\begin{array}{l}-2 \\
\text { Mpa }\end{array}$ & $\begin{array}{l}-2.4 \\
\text { Mpa }\end{array}$ & Unprimed & Mean \\
& Mpa & 35 & 35.3 & 35.3 & 34.6 & 36.3 & 36 & 36 & 35.33 \\
\hline PEG & 34 & 35 & 35.6 & 35.6 & 35.6 & 35.6 & 36.3 & 36.3 & 35.62 \\
\hline Mannitol & 34.6 & 35 & 35.6 & 35.1 & 36 & 36.1 & 36.1 & \\
\hline Mean & 34.3 & 35 & 35.5 & 35.5 & 35.1 & $\mathrm{a}$ & $\mathrm{a}$ & \\
& $\mathrm{C}$ & $\mathrm{bc}$ & $\mathrm{ab}$ & $\mathrm{Ab}$ & $\mathrm{B}$ & $\mathrm{A}$ & $\mathrm{a}$ & \\
&
\end{tabular}

LSD at 5\% level of probability for osmotic potential $=0.78$

\section{Days to edible maturity as affected by} seed priming

It is evident from the data in Table 2 that priming agents and their interaction with osmotic potential had non-significant effect on days to maturity whereas osmotic potential had significant $(\mathrm{P} \leq 0.05)$ effect on days to maturity.

Table 2 represents data on number of days from seed sowing to first pod harvest.
Overall, it took 41 to 44 days to first pod harvest. Sowing dry seeds took 43.6 days to pods harvest compared to priming with pure water which took 40.8 days. Effect of osmotic potential from -1.2 to $-2.4 \mathrm{Mpa}$ is at par with unprimed seed. The difference of a day or two to first pod harvest may not be important to small farmers but may have a big difference for commercial farmers.

Table 2. Days to maturity as affected by seed priming

\begin{tabular}{|c|c|c|c|c|c|c|c|c|c|}
\hline Priming Agent & \multicolumn{9}{|c|}{ Osmotic potential } \\
\hline & $\begin{array}{l}0 \\
\text { Mpa }\end{array}$ & $\begin{array}{l}-0.4 \\
\text { Mpa }\end{array}$ & $\begin{array}{l}-0.8 \\
\text { Mpa }\end{array}$ & $\begin{array}{l}-1.2 \\
\text { Mpa }\end{array}$ & $\begin{array}{l}-1.6 \\
\text { Мра }\end{array}$ & $\begin{array}{l}-2 \\
\text { Mpa }\end{array}$ & $\begin{array}{l}-2.4 \\
\text { Mpa }\end{array}$ & Unprimed & Mean \\
\hline PEG & 40.6 & 42.3 & 41.6 & 42.6 & 42.6 & 43.3 & 43.6 & 43.3 & 42.54 \\
\hline Mannitol & 41 & 42 & 43 & 43 & 43 & 43.3 & 43.3 & 44 & 42.83 \\
\hline Mean & $\begin{array}{l}40.8 \\
\mathrm{C}\end{array}$ & $\begin{array}{l}42.1 \\
B \\
\end{array}$ & $\begin{array}{l}42.3 \\
b\end{array}$ & $\begin{array}{l}42.8 \\
\mathrm{ab}\end{array}$ & $\begin{array}{l}42.8 \\
\mathrm{ab}\end{array}$ & $\begin{array}{l}43.3 \\
\text { A }\end{array}$ & $\begin{array}{l}43.5 \\
\mathrm{~A}\end{array}$ & $\begin{array}{l}43.6 \\
\mathrm{a} \\
\end{array}$ & \\
\hline
\end{tabular}

LSD at $5 \%$ level of probability for osmotic potential $=0.84$ 
Plant height $(\mathrm{cm})$ as affected by seed priming

Statistical analysis of the data revealed that osmotic potential of the priming solution significantly $(\mathrm{P} \leq 0.05)$ affected plant height but no significant effect of priming agents and its interaction with osmotic potential was found on plant height.

Table 3 represents data on plant height as affected by priming okra seed versus sowing dry seeds. Increase or decrease in plant height is a complex phenomenon and is a result of cumulative effects of many factors, planting densities, light, plant growth pattern, availability of nutrients and age play their role in increase or decrease in plant height.

In our experiment (Table 3), plants raised from dry seeds had attained significantly less height at the $80^{\text {th }}$ day as compared to other treatments. This period of 80 days starts from date of sowing the seeds. Plants in other treatments grew comparatively taller. Irrespective of the priming agents (PEG and Mannitol), Plants raised from seeds primed with PEG or Mannitol solutions at 0 to $-1.2 \mathrm{Mpa}$ osmotic potential, had attained statistically maximum plant height. Priming seeds with solution having $2 \mathrm{Mpa}$ or below osmotic potential had resulted in dwarf okra plants.

Table 3. Okra plant height (cm) as affected by seed priming

\begin{tabular}{|l|l|l|l|l|l|l|l|l|l|}
\hline Priming Agent & \multicolumn{10}{|c|}{ Osmotic potential } \\
& $\begin{array}{l}\text { Mpa } \\
\end{array}$ & $\begin{array}{l}-0.4 \\
\text { Mpa }\end{array}$ & $\begin{array}{l}-0.8 \\
\text { Mpa }\end{array}$ & $\begin{array}{l}-1.2 \\
\text { Mpa }\end{array}$ & $\begin{array}{l}-1.6 \\
\text { Mpa }\end{array}$ & $\begin{array}{l}-2 \\
\text { Mpa }\end{array}$ & $\begin{array}{l}-2.4 \\
\text { Mpa }\end{array}$ & Unprimed & Mean \\
\hline PEG & 92.04 & 91.74 & 91.43 & 94.48 & 89.91 & 88.39 & 84.73 & 78.02 & 88.84 \\
\hline Mannitol & 92.04 & 91.74 & 92.35 & 94.45 & 92.96 & 85.34 & 82.29 & 76.60 & 88.47 \\
\hline Mean & 92.04 & 91.74 & 91.89 & 94.47 & 91.43 & 86.86 & 83.51 & 77.31 & \\
& $\mathrm{ab}$ & $\mathrm{ab}$ & $\mathrm{ab}$ & $\mathrm{a}$ & $\mathrm{b}$ & $\mathrm{c}$ & $\mathrm{d}$ & $\mathrm{e}$ & \\
\hline
\end{tabular}

LSD at 5\% level of probability for osmotic potential=2.95

Absolute growth rate (AGR) of Okra plant as affected by seed priming

Statistical analysis of the data (Table 4) indicated that priming agents and their interactions with osmotic potential had insignificant effect on absolute growth rate whereas osmotic potential had significant $(\mathrm{P} \leq 0.05)$ effect on absolute growth rate (Dry matter production plant ${ }^{-1}$ day $^{-1}$ ).

Data in Table 4 regarding the effect of osmotic potential on absolute growth rate
(AGR) showed that significantly higher absolute growth rate of 0.92 to $1.01 \mathrm{~g}$ was recorded for osmotic potential from 0 to -1.2 $\mathrm{Mpa}$ as compared to other treatments. It was followed by 0.79 and $0.67 \mathrm{~g}$ AGR under osmotic potential of -1.6 and -2 Mpa respectively while the least absolute growth rate of $0.52 \mathrm{~g}$ was observed for plants from unprimed seeds which were statistically at par with the AGR of plants from seeds primed at -2.4 Mpa osmotic potential.

Table 4. Absolute growth rate of Okra plant as affected by seed priming (gm)

\begin{tabular}{|l|l|l|l|l|l|l|l|l|l|}
\hline Priming Agent & \multicolumn{9}{|c|}{ Osmotic potential } \\
\hline & 0 & $\begin{array}{l}-0.4 \\
\mathrm{Mpa}\end{array}$ & $\begin{array}{l}-0.8 \\
\mathrm{Mpa}\end{array}$ & $\begin{array}{l}-1.2 \\
\mathrm{Mpa}\end{array}$ & $\begin{array}{l}-1.6 \\
\mathrm{Mpa}\end{array}$ & $\begin{array}{l}-2 \\
\mathrm{Mpa}\end{array}$ & $\begin{array}{l}-2.4 \\
\mathrm{Mpa}\end{array}$ & Unprimed & Mean \\
& .96 & .95 & .93 & 1.05 & .81 & .68 & .50 & .51 & .80 \\
\hline PEG & .96 & .90 & .91 & .97 & .77 & .67 & .61 & .53 & .79 \\
\hline Mannitol & $.96 \mathrm{a}$ & $.92 \mathrm{a}$ & $.92 \mathrm{a}$ & $1.01 \mathrm{a}$ & $.79 \mathrm{~b}$ & $.67 \mathrm{c}$ & $.55 \mathrm{~d}$ & $.52 \mathrm{~d}$ & \\
\hline Mean &
\end{tabular}

LSD at $5 \%$ level of probability for osmotic potential $=0.09$ 
Relative growth rate (RGR) of Okra plant as affected by seed priming

It is evident from statistical analysis of the data relating to RGR that osmotic potential significantly $(\mathrm{P} \leq 0.05)$ affected $\mathrm{RGR}$ while priming agents and its interaction with osmotic potential had insignificant effect on RGR.

Table 5 represent data on Relative growth rate, which here mean per day increment (expressed in milligrams) for a gram of plant dry weight. The figures represented in Table 5 are mathematical manipulation of actual data represented in Table 5.

Plants from unprimed seeds have maximum relative growth rate (RGR) compared to plants from seeds primed with solution at higher osmotic potential. Plants from seeds primed with solution at -2 to $-2.4 \mathrm{Mpa}$ osmotic potential have statistically similar behavior to those from unprimed seeds.

Table 5. Relative growth rate of okra plant in mg

\begin{tabular}{|l|l|l|l|l|l|l|l|l|l|}
\hline $\begin{array}{l}\text { Priming } \\
\text { Agent }\end{array}$ & \multicolumn{10}{|c|}{ Osmotic potential } \\
\hline & $\begin{array}{l}\text { Mpa } \\
\text { Mpa }\end{array}$ & $\begin{array}{l}-0.4 \\
\text { Mpa }\end{array}$ & $\begin{array}{l}-1.2 \\
\text { Mpa }\end{array}$ & $\begin{array}{l}-1.6 \\
\text { Mpa }\end{array}$ & $\begin{array}{l}-2 \\
\text { Mpa }\end{array}$ & $\begin{array}{l}-2.4 \\
\text { Mpa }\end{array}$ & Unprimed & Mean \\
\hline PEG & 44.35 & 45.47 & 44.55 & 44.10 & 44.84 & 48.99 & 46.10 & 50.65 & 46.1 \\
\hline Mannitol & 44 & 45 & 46.33 & 45.66 & 47.50 & 48 & 49.66 & 50.66 & 47.1 \\
\hline Mean & $\begin{array}{l}44.17 \\
\mathrm{D}\end{array}$ & $\begin{array}{l}45.2 \\
\mathrm{Bcd}\end{array}$ & $\begin{array}{l}45.4 \\
\mathrm{bc}\end{array}$ & $\begin{array}{l}44.8 \\
\mathrm{Bc}\end{array}$ & $\begin{array}{l}46.1 \\
\mathrm{bc}\end{array}$ & $\begin{array}{l}48.49 \\
\mathrm{Ab}\end{array}$ & $\begin{array}{l}47.8 \\
\mathrm{Abc}\end{array}$ & $\begin{array}{l}50.65 \\
\mathrm{a}\end{array}$ & \\
\hline
\end{tabular}

LSD at 5\% level of probability for osmotic potential $=4.15$

Discussion

\section{Seed priming effect on days to flowering} and maturity

Data in table-1 and 2 shows that priming at high osmotic potential significantly reduced days to edible maturity as compared to unprimed seeds and seeds primed at lower osmotic potential, thismay be due to early emergence of seeds by priming. Our results agree with Murungu et al., [9], Barlow and Haig [10] who reported that priming reduce days to flowering and edible maturity.

Okra plant height $(\mathrm{cm})$ as affected by seed priming

Plant height of primed seed plots was significantly higher than unprimed seed plots. Which is in line with the findings of Mohammadi [12], Bakare and Ukwungwu [14] who have reported that seed priming causes increase in plant height. This can be explained on the basis of emergence. Plants from unprimed seeds may takemore days to emergencethan primed seeds which may results in above ground age difference and thisabove ground age difference may cause differences in plant height.

Seed priming effect on absolute growth rate (AGR)

Data in Table 4 indicate that AGR in plants from unprimed seeds is statistically at par with those primed at $-2.4 \mathrm{Mpa}$ osmotic potential (0.52 and 0.55 respectively). It could be that the lowest osmotic potential did not allow water penetration into seed and thus behaved like unprimed seeds.

The data also indicate gradual improvement in AGR as solution osmotic potential increases from -2 Mpa toward zero.Significantly higher AGR was recorded at osmotic potential in the range of 0 to -1.2 Mpa. Arif et al., [16] had also reported similar results.

Differences in AGR of plants may be due to differences in their above ground age because figures in Table 5are the averages of data recorded at 30 and 60 days after seed 
sowing in field. Plant actually had differences in their life above ground, thoughthe seeds were sown on the same date (day) due to variation in days to germination.

\section{Relative growth rate (RGR) of okra plant} as affected by seed priming

More RGR was recorded for plants from unprimed seeds as compared to plants from primed seeds.Plants from unprimed seeds have delayed flowering and time to edible pod harvest as compared to plants in rest of the treatments. These plants had an increase in RGR at the cost of delayed formation sink for photosynthates (flowers and pods), while plants in other treatments were sending photosynthates to their sinks (flowers and pods), when these plants were focusing on enhancing vegetative growth.

\section{Conclusion and recommendation}

It is concluded that flowering and edible maturity may be speed up and synchronized through seed priming.Growth rate may also be improved through seed priming. Early flowering and edible maturity could be obtained through hydropriming i.e at $0 \mathrm{Mpa}$ while more plant height and absolute growth rate may be obtained through priming seeds at -1.2 Mpa osmotic potential. Maximum relative growth rate may be obtained from unprimed seeds.

\section{Authors 'contributions}

Conceived and designed the experiments: I Rahman, Performed the experiments: I Rahman \& S Ali, Analyzed the data: I Rahman, S Ali \& I Rahman, Contributed reagents/materials/analysis tools: I Rahman, S Ali, I Rahman, M Adnan, M Ibrahim, N Saleem \& IA Khan, Wrote the paper: I Rahman, S Ali, I Rahman, M Adnan, M Ibrahim, N Saleem \& IA Khan.

\section{References}

1. Heydecker W, Higgins J \& Gulliver RL (1973). Accelerated germination by osmotic seed treatment. Nature 246: 4244.
2. Gurusinghe, SH, Cheng Z \& Bradford K J (1999). Cell cycle activity during seed priming is not essential for germination advancement in tomato. Journal of Experimental Botany 50(330): 101-106.

3. Kausar M, Mahmood T, Basra SMA \& Arshad M (2009). Invigoration of low vigor sunflower hybrids by seed priming. Int J Agric Biol 11(5): 521-528.

4. Dursun A \& Ekinci M (2010). Effects of different priming treatments and priming durations on germination percentage of parsley (Petroselinum crispum L.) seeds. Agricultural Sciences 1(1): 17.

5. Moradi, A., \& O. Younesi. 2009. Effects of osmo and hyropriming on seed parameters of grain sorghum (Sorghum bicolor L.). Australian Journal of Basic and Applied Sciences 3(3): 1696-1700.

6. Yari L, Aghaalikhani M \& Khazaei F (2010). Effect of Seed priming duration and temperature on seed germination behavior of bread wheat (Triticum aestivum L.). ARPN Journal of Agricultural \& Biological Science 5(1): 5-8.

7. Neamatollahi E, Bannayan M, Darban AS \& Ghanbari A (2009). Hydropriming and osmopriming effects on cumin (Cuminum Cyminum L.) seeds germination. World Academy of Science, Engineering \& Technology 57: 526-529.

8. Bujalski W, Nienow AW, Maude RB \& Gray D (1993). Priming responses of leek (Allium porrum L.) seeds to different dissolved oxygen levels in the osmoticum. Annals of applied biology 122(3): 569-577.

9. Murungu FS, Chiduza C, Nyamugafata $P$, Clark LJ \& Whalley WR (2004). Effect of on-farm seed priming on emergence, growth and yield of cotton and maize in a semi-arid area of Zimbabwe. Experimental agriculture 40 (01): 23-36.

10. Barlow EWR \& Haigh AM (1986). 
Effect of seed priming on the emergence, growth and yield of UC 82B tomatoes in the field. In II International Symposium on Processing Tomatoes, XXII IHC 200 (153-164).

11. Basra SM, Ullah EHSAN, Warraich EA, Cheema MA \& Afzal I (2003). Effect of storage on growth and yield of primed canola (Brassica napus) seeds. International journal of agriculture and biology 5(2): 117-120.

12. Mohammadi GR (2009). The effect of seed priming on plant traits of latespring seeded soybean (Glycine max L.). American-Eusian Journal of Agriculture \& Environment Science 5(3): 322-326.

13. Khan HA, Ayub CM, Pervez MA, Bilal RM, Shahid MA \& Ziaf K (2009).
Effect of seed priming with $\mathrm{NaCl}$ on salinity tolerance of hot pepper (Capsicum annuum L.) at seedling stage. Soil and Environment 28(1): 8187.

14. Bakare SO \& Ukwungwu MN (2009). On-farm evaluation of seed priming technology in Nigeria. African Journal of General Agriculture 5(2): 93-97.

15. Savello PA, Martin FW \& Hill JM 1980. Nutritional composition of okra seed meal. J Agric Food Chem 28: 1163-1166.

16. Arif M, Jan MT, Khan NU, Khan AH, Khan MJ \& Munir IQBAL (2010). Effect of seed priming on growth parameters of Soybean. Pak J Bot 42(4): 2803-2812. 